\title{
The Role of Corporate Culture in Maintaining Organizational Operations during the Global Financial Crisis
}

\author{
Hala Abdulqader Sabri \\ University of Petra, Amman-Jordan \\ habdulqader@uop.edu.jo
}

\begin{abstract}
The global financial crisis that unfolded in 2008 presents leaders and managers with many challenges. Yet, the lessons of this crisis also present opportunities to create more responsive and flexible organizations capable of overcoming the risks and troubles more effectively. However, in the midst of this crisis it is apparent that most of the attention seems to be devoted to changing regulatory structures and rules that affect corporate governance and the financial markets. This paper argues that the root causes of such crisis are deep and unlikely to be addressed through public policy or external means alone. Most of the problems during this financial crisis can be traced to that most CEOs and executives did not actually pay attention to their company's culture as they did with regard to their profits, assets, brands, and quality of products and services. The paper then explores the vulnerability of firms whose executives fail to manage their company's culture at the time of crisis with as much thoroughness as they apply to managing their financial, operational or technology risks. Finally, the paper lays out a leadership and management strategy based on the strengths of maintaining a strong corporate culture guided by adherence to the core values of the organization.
\end{abstract}

\section{Keywords: Corporate Culture, Organizational Operation, Global Crisis}

\section{Introduction}

The current financial crisis has been the worst economic episodes in modern history since the Great Depression (Bernanke, 2009). As a result of this crisis the most important industrial economies, like those of the United States, China, India, Japan, Germany, and Britain, are in deep recession that triggered a reaction in which almost all governments engaged in extensive deficit spending to infuse liquidity into financial markets and to fight the economic downturn. Bernanke (2009) called on Western countries not to overlook the impact that the crisis has, particularly on many citizens of countries that struggle economically even when the global economy is doing well. Many factors directly and indirectly caused the ongoing global financial crisis, with experts placing different weights upon particular causes. Some of these causes relate to particular markets, such as the stock or housing markets, while others relate, more broadly, to the global economy. Yet, in the midst of this crisis it is apparent that most of the attention seems to be dedicated to changing regulatory structures and rules that affect corporate governance and the financial markets. However, the complexity and interdependence of many of the causes, as well as political, economic and organizational interests, have resulted in a variety of views who describe the root causes of the crisis as deep and unlikely to be addressed through economic factors or external means alone. In this regard, Anderson (2009) argues that in trying to predict the future, putting a lens of sociologist or anthropologist would help see things differently. In this paper, the author introduces the idea that corporate culture itself offers a means of protection of many financial risk factors and can be addressed in times of crisis to increase chances of survival. The paper argues that many of the problems, during the current financial crisis, can be traced to that most CEOs and executives did not actually pay attention to their corporate culture as they did with regard to their profits, assets, brands, and quality of products and services. The paper concludes by pointing to a leadership and management plan based on the strengths of creating and maintaining a strong corporate culture that should be guided by adherence to the core values of the organization.

Problem Assessment: In analyzing the root causes of the crisis, Tett (2011) argues that because the internal structures of many corporations were fragmented, senior executives could not see the scale of risky activity that their employees were engaging in before the crisis hit the markets in 2007. Moreover, regulators themselves tended to operate in a disintegrated manner that made it hard for them to track what was happening in the market as a whole (Tett, 2011). These complexities created a drop backwards 
with regard to the gains that have transformed the business world with the advancement and focus on corporate culture which has become an increasingly important element for academics as well as practitioners in the last twenty-five years. Consequently, the business world everywhere was filled with corporate scandals that shocked people's beliefs about the culture of many corporations. Those scandals and accounting frauds, involving companies such as AIG, Enron, OmniMedia, Siemens, Societe Generale, Tyco, and WorldCom, triggered much interest on global ethical leadership (Hsu, 2008). Green (2009) confirmed, for instance, that the economic crisis provides an opportunity for companies to get serious about "Ethics" and called on the Boards to establish an "Ethics Officer" and develop an "Ethics based Corporate Culture". Hence, American and German companies appointed chief risk officers (CRO) who exert much influence on making strategic investment decisions and oversee ethical behavior of the corporate risky investments (Hsu, 2008). Moreover, many groups started calling corporations for a change in their corporate culture that supports more ethical and responsible finances instead of simply chasing profit at all cost to maximize shareholders' value (Tett, 2011). The Enron case of ethical failure, which was the biggest failure in U.S. history in 2001, is one pertinent introduction to the current market meltdown that consists of more than a series of questionable business dealings (Lease, 2006). Enron initially gained a reputation for fast growth and high returns. When it was unable to sustain it, managers fabricated stories of growth to maintain the reputation, believing that they would be able to revert back. The fabrication and cheating became ingrained in their culture that it became the objective of the organization rather than its business objectives. The misleading continued till it consequently led to death of the organization and the rapid end of its top managers (Gains-Ross, 2008). According to Schein (1996), Enron's organizational culture was a breeding ground for ethical misbehavior among its employees, particularly its top executives. Sims and Brinkman (2003) showed how Enron's organizational culture, as influenced by its leaders, has led to the crisis. They, specifically, argued that Enron's executives used Schein's (1997) five primary mechanisms (attention, reaction to crisis, role modeling, allocation of rewards, and criteria for selection and dismissal), "to reinforce a culture that was morally flexible, opening the door to ethics degeneration, lying, cheating, and stealing" (Sims \& Brinkman, 2003).

\section{Theoretical Review}

As organizations are increasingly facing external pressures and seek to manage change, the vital role that culture plays in successful change is being realized. Many believe, therefore, that the interest in organizational culture stems from the belief that it influences behavior, leadership styles, decisionmaking and organizational strategies and performance (Schein, 2005; Denison, 1984; Kotter \& Heskett, 1992).

Organizational Culture: Organizational culture is an idea in the field of organizational studies and management which describes the psychology, attitudes, experiences, beliefs and values (personal and cultural) of an organization. Although it is difficult to get consensus about the definition of organizational culture, several constructs are commonly agreed upon, that organizational culture is holistic, historically determined, related to anthropological concepts, socially constructed, soft, and difficult to change. Schein (1996:229) defines organizational culture as the "shaped norms, values and assumptions of how organizations function". Ravasi and Schultz (2006) define organizational culture as "a set of shared mental assumptions that guide interpretation and action in organizations by defining appropriate behavior for various situations". Hill and Jones (2001) state it is the "beliefs and ideas about what kinds of goals members of an organization should pursue and ideas about the appropriate kinds or standards of behavior organizational members should use to achieve these goals." Handy (1981) argues also that organizational culture is shaped by multiple contextual factors. The principal ones are: history and ownership, size, technology, goals and objectives, the environment and the nature of the people. Schein (1996) asserts that the main reason why cultures develop in organizations is due to external adaptation and internal integration. External adaptation reflects an evolutionary approach to organizational culture, and internal integration is an important function since social structures are required for organizations to exist.

The Power and Impact of Organizational Culture: Organizational culture is reflected in the way people perform tasks, set objectives, and administer the necessary resources to achieve objectives. Culture affects the way individuals make decisions, feel, and act in response to the opportunities and threats affecting the organization. Hence, Culture strongly influences business results. Schein (1996) pertains that cultures develop and persist because they help an organization to survive and flourish. Schein (1996) 
adds also that if the culture is valuable, it will generate sustained competitive advantages. Additionally, several researches suggest that many outcomes have been associated, directly or indirectly, with organizational culture (Deal \& Kennedy, 1982). A healthy organizational culture may provide competitive advantage derived from customer service and innovation; team integration; robust alignment towards goal achievement, and effective employee performance and high morale. Deal and Kennedy (1982) reported that companies who consistently score high performance also have positive and strong cultures. Similarly, Peters and Waterman (1982) suggest that excellent organizations have a set of shared common values and that their cultures are strong. They also showed that organizations that foster strong cultures have clear values that give employees a reason to embrace the culture. It is generally accepted that strong corporate cultures are 'good', while weak cultures are 'bad' for an organization. "Strong culture" is said to exist where staff respond to stimulus because of their alignment to organizational values. Conversely, there is "weak culture" where there is little alignment with organizational values and control must be exercised through extensive procedures and bureaucracy. Kilmann, et al., (1986) define strong cultures as those where organization members place pressure on other members to adhere to norms. Byrne (2002) indicates that 'a strong organizational culture will exert more influence on employees than a weak one. If the culture is strong and supports high ethical standards, it should have a very powerful and positive influence on employee behavior.' Culture can be a major contributing factor to organizational success or failure through a provision of mindsets that promote stability and change. Hence, two fundamental forces operate in all organizations, one maintaining things as they are and another promoting change. The latter can better explain the role of culture in organizational performance. A Corporate Leadership Council's study (2002) found that cultural traits such as risk taking, internal communications, and flexibility are some of the most important drivers of performance, and may impact individual performance. Furthermore, innovativeness, productivity through people, and the other cultural factors cited by Peters and Waterman (1982) also have positive economic consequences. Denison, et al., (2004) also suggest that culture contributes to the success of the organization, but found that organizational culture is impacted by national culture. Additionally, Clarke (2006) realized that a safety climate is related to an organization's safety record.

Leadership and Culture: The relationship between organizational culture and leadership is denoted in the works of Schein (1996), Bass (1985), Bass \& Avolio (1993) and Argyris (1974). According to these writers, if culture is seen as an integral part of the organization, then the thinking, feeling, and responses of leaders are molded by the culture. Argyris (1974) sustains, however, that organization's leaders, especially it's CEO and other top leaders, play a vital role in shaping its culture. Schein (1996) observes that organizational culture and leadership are intertwined. He argues that leadership style is a critical factor of the quality of any organizational culture. Good managers lower anxiety, creating a sense of confidence and security. By communicating truthfully, they build trust; acknowledge urgency, focusing teams on the most important projects and goals. All these actions engage employees in their work and connect them to the larger organization. Moreover, Schein (2005) asserts that the founding of an organization is a critical period in the life of the organization and the development of its culture. During the formation process the founders of a company creates and shapes the cultural traits of the organization which reflects their values and beliefs. Through this dynamic ongoing process, the leader creates and is in turn shaped by the organizational culture. Bass (1985) demonstrates the relationship between leadership and culture by examining the impact of different styles of leadership on culture. Similarly, Brown (1995) observes that good leaders need to develop the skills that enable them to alter aspects of their culture in order to improve their organizational performance.

Leading through Culture Change During Crisis: In his book "Managing in Turbulent Times," Drucker (1980) argues that the first order of business must be to survive. Surviving, however, requires both strong management and extraordinary leadership that will help identify organizational core values, levels of commitment, and strength of character. Nelson and Cohen (2010) indicate that many leaders, unfortunately, do not recognize the influence that organizational culture has on the past, present, and future accomplishments of their organizations. Even more important is their lack of understanding about how they influence the culture. Turmoil and instability of any kind can affect an organization's culture. However, in today's economic crisis, Kitching et al., (2009) believe that some organizations still continue to exceed customer expectations, maintain employee productivity, and innovate to gain a competitive edge, all within the confines of reductions in staff, budgets and incomes and hence, cultivating a positive organizational culture in a negative economic one. Hence, crisis makes culture more important. Kitching et al., (2009) add also that with layoffs and losses are increasing today, leaders are looking for ways to 
assign manageable workloads, improve morale, and lower anxiety. Key to this success is leadership that encourages a collaborative, synergetic, and creative work environment. Therefore, creating a positive organizational culture has become vital to corporations nowadays. As growth slows and profits lag, businesses are examining key issues of their culture to increase employee motivation and produces more effective performance.

\section{Current Models of Culture-Change during Crisis}

Several authors (Nelson \& Cohen, 2010; Nadler \& Tushman, 1997; Recklies, 2001; Schein, 2005) have suggested different models for culture change during turmoil and instability. Nelson and Cohen (2010) suggest that leaders need to prepare for change and take necessary steps to protect and adjust their culture through efficient planning before, during, and following turbulent times. To meet the challenge and achieve a successful culture shift, they recommend identifying the existing culture; proactively influencing the organization's culture; revisiting the core purpose and values and communicating and reinforcing the values. Nadler and Tushman (1997) presented a model by which leaders can explore their organization's culture and determine if change is needed. The model views the organization as a system that draws inputs from both internal and external sources (strategy, resources and environment) and transforms them into outputs (activities, behavior and performance) at three levels the individual, the group and the organization. In the transformation process, the organization is composed of four subsystems, dependent on each other: the work, the people, the formal and the informal organization. To achieve effective change, Nadler and Tushman (1997) proposed that leaders should attend to all four components, not just one or two. Recklies (2001) presented the seven ' $S$ ' model (staff, skills, systems, style/culture, shared values, strategy, and structure) which represents the organization as a set of interconnected and interdependent sub-systems and offers another starting point for organizations facing culture change (Recklies, 2001). To be effective, an organization must have a high degree of internal alignment among all the seven elements that are distinguished in hard feasible elements that can be found in strategy statements, corporate plans, organizational charts and other documentations, and soft hidden and continuously changing elements such as capabilities, values and elements of corporate culture. However, Recklies argues that the soft elements are determined by the people in the organization and can have a great impact on structures, strategies and systems of the organization (Recklies, 2001). Among the most referred to model on culture change during crisis is Schein's leadership model of culturechange. Schein (1997) suggested five primary mechanisms and five secondary mechanisms by which leaders may directly achieve culture change. The 'primary mechanisms' originate in the ways by which leaders affect culture change through their actions: attention, reaction to crises, role modeling, allocation of rewards and criteria for selection and dismissal. The secondary mechanisms are means by which leaders may indirectly affect culture change: organizational structure, systems and procedures, design of facilities, stories, legends myths, and formal statements.

\section{Conclusion}

Inspired by other research in the field of crisis management during turbulent times, this study introduced the idea that corporate culture offers a means of protection of many risk factors that can be addressed in times of crisis to increase chances of survival. The analysis showed that many of the problems, during the world's financial crisis, originated because most executives did not pay attention to their corporate culture as they did with regard to their profits, assets, brands, and quality of products and services. The researcher made an attempt to present different models of culture change which all agree on that risks and challenges require commitment to advanced leadership skills to create an adaptive organizational culture that keeps current with the latest developments and reacts more quickly and effectively to all possible change in the environment. Finally, this study is theoretically oriented, it has surfaced, however, important issues for future research to consider the other too many factors that have played a part in creating today's economic crisis that will be studied and analyzed for decades. 


\section{References}

Anderson, R. (2009). Cultural Context of the 2008 Financial Crisis. The Society Pages, online at http:// thesocietypages.org/eye/2009/03/20/cultural-contexts-of-the-2008-financial-crisis/

Argyris, C. (1974). Theory in Practice, Jossey bass: San Francisco.

Bass, B. M. (1985). Leadership and performance beyond expectations. New York: Free Press.

Bass, B. M. \& Avolio, B. J. (1993). Transformational leadership: A response to critiques. In M.M. Chemers \& R. Ayman (eds.), Leadership theory and research: Perspectives and direction (pp. 49-88). San Diego, CA: Academic Press.

Bernanke, B. S. (2009). Four Questions of the Financial Crisis. A Speech at the Morehouse College, Atlanta, Georgia, Board of Governance of the Federal Reserve System, online at http://www.federalreserve.gov/newsevents/speech/bernanke 20090414a.htm

Brown, A. (1995). Organizational Culture, London: Pitman.

Byrne, J. A. (2002). At Enron, the environment was ripe for abuse", Business Week, online at www.businessweek.com

Clarke, S. (2006). The Relationship between Safety Climate and Safety Performance: A Meta-Analytic Review. Journal of Occupational Health Psychology, 11(4), 315-327.

Corporate Leadership Council. (2002). Building the High-Performance Workforce: A Quantitative analysis of the Effectiveness of Performance Management Strategies. Corporate Executive Board, Washington, DC.

Deal, T. E. \& Kennedy, A. A. (1982). Corporate Cultures: The Rites and Rituals of Corporate life, Reading, Mass: Addison-Wesley.

Denison, D. R. (1984). Bringing corporate culture to the bottom line. Organizational Dynamics, 13(2), 522.

Denison, D. R., Haaland, S. \& Goelzer, P. (2004). Corporate Culture and Organizational Effectiveness: Is Asia Different from the Rest of the World? In: W. H. Mobley (Special Issue Editor), Leadership Challenges in China \& Asia. Organizational Dynamics, 33(1), 98-108.

Drucker, P. (1980). Managing in Turbulent Times, New York: Harper- Collins.

Gains-Ross, L. (2008). Corporate Reputation: 12 Steps for Safeguarding and Recovering Reputation, Hoboken, NJ: John Wiley \& Sons Inc.

Green, S. (2009). Economic Crisis: Risk and Opportunities, Group Chairman, HSBC, UK Speech at the Economic Forum at Davos, January, 29, online from http://www. corporate-eye.com/blog/ 2009/03/economic-crisis-risks-opportunities/

Handy, C. B. (1981). Understanding Organizations, $2^{\text {nd }}$ edition, Harmondsworth, Penguin

Hill, C. \& Jones, G. (2001). Strategic Management: an Integrated Approach, 5 ${ }^{\text {th }}$ edition, New York: Houghton Mifflin Harcourt.

Hsu, D. K. (2008). Organization Behavior Development: Case Studies on Corporate Culture. E-Leader Conference, Krakow-Poland, 9-11 June, online at http://www.gcasa.com/PDF/Krakow\%202008/krakow\%20papers\%20pdf/paper\%20database\%20krakow/Hs u.pdf

Kilmann, R. H., Saxton, M. J. \& Serpa, R. (1986). Issues in Understanding and Changing Culture. California Management Review, 28, 87-94.

Kitching, J., Blackburn, R., Smallbone, D. \& Dixon, S. (2009). Business Strategies and Performance during Difficult Economic conditions. Department of Business Innovation and Skills (BIS), URN 09/1031, online at www.berr.gov.uk/ files/ file51879.doc

Kotter, J. P. \& Heskett, J. L. (1992). Corporate Culture and Performance, New York: Maxwell McMillan International.

Lease, D. R. (2006). From Great to Ghastly: How Toxic Organizational Cultures Poison Companies, The Rise and Fall of Enron, WorldCom, HealthSouth, and Tyco International. Paper presented at the Academy of Business Education, April 6-7, online at http://www.drdavidlease.com/user/David\%20LeaseGreat\%20to\% 20 Ghastly.pdf

Nadler, D. A. \& Tushman, M. L. (1997). Congruence Model, Political, Organism, Oxford University Press

Nelson, P. \& Cohen, E. (2010). Riding the Tiger: Leading through Learning in Turbulent Times, ASTD Press, Nelson Cohen Global Consulting, online at http://nelsoncohen. com/wpcontent/uploads/2010/03/Organizational_Culture.pdf

Peters, T. J. \& Waterman, R. H. Jr. (1982). In Search of Excellence: Lessons From America's Best-Run Companies, New York: Harper and Row. 
Ravasi, D. \& Schultz, M. (2006). Responding to Organizational Identity Threats: Exploring the Role of Organizational Culture. Academy of Management Journal, 49(3), 433-458.

Recklies, R. (2001). Management Models: what they can do and what they cannot do, 7 S Model (Mckinsey 7S). The manager organization, online at http://www.themanager. org/ Models/7S\% 20Model .htm

Schein, E. H. (1985-2005). Organizational Culture and Leadership, 3rd Ed., Jossey-Bass

Schein, E. H. (1997). Organizational Culture and Leadership, online at http://www. tnellen.com/ted/tc/schein.html

Sims, R. R. \& Brinkmann, J. (2003). Enron ethics: Culture matters more than codes. Journal of Business Ethics, 45(3), 243.

Tett, G. (2011). Policymakers learn a new and alarming catastrophe, In Is financial repression the answer? The Economist View, May, 9, online at http:// economistsview.typepad.com/economistsview/financial_system/index.html 